\title{
Do Explicit Warnings Eliminate the Hypothetical Bias in Elicitation Procedures? Evidence from Field Auctions for Sportscards
}

\author{
By JoHn A. LisT*
}

The goal of environmental policy is to protect the well-being of humans and the ecosystems vital to human existence. Because benefit-cost analyses are now required at the federal level, and increasingly at the state level, much attention has been paid to the development of practical, credible approaches for estimating the benefits and costs of environmental programs. Although policy makers have a good handle on measuring the explicit costs associated with increased environmental protection, at present several disparate approaches are utilized to measure economic values of environmental goods and services. Arguably the most contentious of these approaches is the Contingent Valuation Method (CVM), which allows the researcher to measure the total value of the commodity in question (see Peter A. Diamond and Jerry A. Hausman's [1994] critical review). Chief amongst these concerns is whether hypothetical bias is inherent in CVM responses.

Some recently published studies provide evidence that suggests important differences exist between responses from real and hypothetical valuation questions. ${ }^{1}$ Recognizing this shortcoming, researchers have adopted both ex ante and ex post techniques to overcome hypothetical bias. Although these attempts have not been completely successful in dealing with hypothetical bias, Ronald G. Cummings and Laura O. Taylor (1999) present evidence from laboratory

\footnotetext{
* Department of Agricultural and Resource Economics, 2200 Symons Hall, University of Maryland, College Park, MD 20742 (e-mail: jlist@arec.umd.edu). I would like to thank Laura Taylor and Ronald Cummings for providing their experimental survey. They also provided numerous suggestions and lively discussion of the important issues. Two anonymous reviewers also provided constructive comments. Finally, I thank Craig Gallet, Charles Holt, Elias Khalil, Matthew Rabin, Jason Shogren, and Mark Strazicich for providing insightful comments. I have also benefited from discussions with Vernon Smith. The raw data from the experiments are available upon request.

${ }^{1}$ See List and Jason F. Shogren (1998b) for a review.
}

experiments that indicates hypothetical bias can be overcome by an appropriate ex ante design they refer to as a "cheap talk" scheme. ${ }^{2}$ The underlying premise behind Cummings and Taylor's design is that by making hypothetical bias an integral part of the contingent value questionnaire, the researcher can induce truthtelling. Their cheap talk experiments validated this conjecture, as hypothetical bias was effectively eliminated in open referenda for three public goods.

The goal of this study is to take the cheap talk design to a well-functioning marketplace and auction off sportscards. Besides providing a field validity test, I also explore the generality of Cummings and Taylor's findings by examining whether experience with the good in question affects hypothetical bias through inclusion of both card dealers and nondealers in the field auctions. The theory of value formation suggests that experienced bidders may not be easily swayed by the cheap talk design as they have a well-structured preference ordering for the good in question and should therefore rely on few, if any, external signals when formulating their value.

\section{Experimental Design}

This study complements Cummings and Taylor (CT hereafter) by taking their methodology to the field. They designed a classroom experiment with student participants to examine whether a cheap talk script describing the nature of hypothetical bias can eliminate the gap between intentions and actions. ${ }^{3}$ Their experiment was designed to satisfy some of the contingent valuation criteria as proposed by the National

\footnotetext{
${ }^{2}$ Note, however, that "short cheap talk" experiments have not eliminated hypothetical bias (see, e.g., Gregory Poe et al. [1997] and Cummings and Taylor [1999]).

${ }^{3}$ Cummings and Taylor also used data from adult participants for their noncheap talk experiments.
} 
Oceanic and Atmospheric Administration's (NOAA) blue-ribbon panel-e.g., dichotomous choice questions in a referendum format. CT find that although a short cheap talk script does not mitigate hypothetical bias, a longer version does eliminate hypothetical bias.

The current study extends CT's work in numerous dimensions. First, I use subjects of all ages in an actual marketplace rather than students in the lab. ${ }^{4}$ Another significant difference is that I have two heterogeneous groups of subjects-those that have market experience with the good (sportscard dealers) and those that have limited experience (nondealers). ${ }^{5}$ A third disparity is that I gather data via one-on-one personal interviews, whereas CT gather data in a group setting. Since CVM questions oftentimes involve complex scenarios that require careful explanation, close control of the pace of the interview is necessary. For this, and other important reasons, the method of choice for most CVM surveys is one-on-one in-person interviews (see, e.g., Robert Cameron Mitchell and Richard T. Carson, 1989). These three features of my field experiments provide increased realism, making the valuation environment as close as possible to most $\mathrm{CVM}$ and market environments.

A further difference between the current study and CT's is that I use an incentivecompatible second-price sealed-bid auction instead of the dichotomous choice referendum design, as advocated by the NOAA panel. Since both allocation mechanisms are theoretically in-

\footnotetext{
${ }^{4}$ As elaborated on in List and David Lucking-Reiley (2000), field experiments are a relatively new innovation to gather unique data. List and Lucking-Reiley (2000) ran 328 auctions at sportscard shows to analyze the efficacy of the uniform-price auction when participants have multi-unit demand. List and Shogren (1998a) employ experimental auctions of sportscards at card shows to investigate related contingent valuation questions; the present paper employs the same card-show methodology as these papers. Field experiments present a trade-off: they give up some of the controls of a laboratory experiment (such as induced valuations) in exchange for increased realism, and therefore provide a useful middle ground between the tight controls of the laboratory and the vagaries of completely uncontrolled field data.

${ }^{5}$ Given the proliferation of sportscard auctions-on the internet, by mail and phone, and in person-one can safely assume that most (if not all) of the participants have previous experience with bidding mechanisms (see, e.g., Sports Collectors' Digest, a weekly publication filled with advertisements for sportscard and sports memorabilia auctions).
}

centive compatible, I am comfortable with the pragmatic choice of the allocation institution. Finally, I use a private good, whereas CT use public goods. Although analysis of a public good better replicates a CVM study, I make the choice of auctioning off a private good because it has a natural market benchmark that acts as an external validity test (see, e.g., Don L. Coursey et al., 1987; Helen Neill et al., 1994; Cummings et al., 1995, who also use private goods). In addition, use of a private good allows a strict test of the CVM and the cheap talk design. This benefit is pointed out by Mitchell and Carson (1989 p. 193): "if people cannot accurately value goods of this kind [private] in hypothetical markets, it is unlikely they would be able to improve their performance when asked to value public goods."

\section{A. The Field Design}

I conducted approximately equal numbers of three treatments: hypothetical, hypothetical with cheap talk, and actual Vickrey secondprice auctions, with different bidders in each auction. I also experimented with bidder type, conducting some experiments with professional card dealers and others with nondealers. This design was employed to capture the distinction between the potential hypothetical biases associated with bidders having market experience and those with relatively less market experience. Sportscards have many favorable characteristics for a calibration exercise including familiarity, the ability to deliver, and an abstract quality beyond the normal market good (List and Shogren, 1998a). I conducted the treatments in December 1998 at a sportscard show in Tampa, FL, where there was a large supply of card collectors.

For all treatments, I auctioned off a Cal Ripken, Jr. 1982 Topps Traded baseball card, which had a book value in the range of $\$ 200-$ $\$ 250$ (depending on which magazine publication was consulted). All auctions displayed the same sportscard to all bidders-a Cal Ripken, Jr. PSA-graded "PSA 8 near-mint/mint" baseball card. To perform the simplest possible test of hypothetical bias, I chose an allocation mechanism-William Vickrey's (1961) second-price auction-which has proved straightforward in other field experiments. While not impeccable, the second-price auction has performed reasonably 
well in revealing preferences for both induced and noninduced value auctions (see, for example, John Kagel's [1995] evaluation). ${ }^{6}$

\section{B. Experimental Procedure}

Each participant's experience followed four steps: (1) inspection of the good, (2) learning the auction rules, (3) placing one bid, and (4) conclusion of the transaction. In Step 1, a potential subject approached the administrator's table and inquired about the sale of the sportscard displayed on the table. The monitor then invited the potential subject to participate in an auction for the sportscard that would take about five minutes. If the individual agreed, the monitor briefly explained that we were auctioning off the sportscard displayed on the table. The participant could pick up and visually examine the card. The card was sealed with the appropriate grade clearly marked on the cardholder. The monitor worked one-on-one with the participant and no time limit was imposed on his or her inspection of the card.

In Step 2, the administrator gave the participant an instruction sheet that consisted of two parts: (1) an auction rules sheet which also included an illustrative example, and (2) a bidding sheet. ${ }^{7}$ In the actual auction treatments, subjects read that "the winner of the card will pay a price equal to the amount of the secondhighest bid." For the hypothetical auctions, I follow CT's nomenclature and state: "suppose you were to bid on the sportscard on the table, if the winner of the card were to pay a price equal to the amount of the second-highest bid, how much would you bid?" Subjects participating in the hypothetical with cheap talk auctions were read the cheap talk script just prior to placing their hypothetical bid. The general

\footnotetext{
${ }^{6}$ The empirical evidence concerning the demand revelation properties of Vickrey second-price auctions is mixed, and remains a point of serious debate. In a recent study, List and Shogren (1999) found that in second-price auctions for consumption goods, subjects submit relatively low bids in early rounds of multiple-round auctions, but bids quickly stabilize after 1 or 2 trials-after subjects received important market feedback. As mentioned in footnote 5, the proliferation of auctions for sportscards has presumably provided important market experience to my subjects, who were all recruited on the floor of a sportscard show.

${ }^{7}$ Appendix A contains a copy of the experimental instructions.
}

cheap talk script is from CT, with necessary changes due to differences in the allocation mechanism and good. Excerpts of the script read as follows:

... in a recent study, several different groups of people bid on a sportscard just like the one you are about to bid on. Payment was hypothetical for these groups, as it will be for you. No one had to pay money if they won the sportscard. The results of these studies were that on average, across the groups, people overstated their actual willingness to pay by 150 percent. That's quite a difference, isn't it?

We call this a "hypothetical bias." Hypothetical bias is the difference that we continually see in the way people respond to hypothetical situations as compared to real situations ... .

How can we get people to think about their bid in a hypothetical auction like they think in a real auction, where if they win they'll really have to pay money? How do we get them to think about what it means to really dig into their pocket and pay money, if in fact they really aren't going to have to do it?

Let me tell you why I think that we continually see this hypothetical bias, why people behave differently in a hypothetical auction than they do when the auction is real. I think that when we bid in a hypothetical auction we bid our best guess of what the good is really worth on the open market. But, when the auction is real, and we would actually have to spend our money if we win, we think a different way: if I spend money on this, that's money I don't have to spend on other things ... we bid in a way that takes into account the limited amount of money we have ... . This is just my opinion, of course, but it's what I think may be going on in hypothetical auctions.

So if I was in your shoes ... I would ask myself: if this were a real auction, and I had to pay $\$ \mathrm{X}$ if I win: do I really want to spend my money this way? If I really did, I would bid \$X; if I didn't, I would bid less than $\$ \mathrm{X} \ldots$..

In any case, I ask you to bid just exactly as you would bid if you were really going to face the consequences of your bid: which is to pay money if you win. Please keep this in mind in our auction. 
After the monitor answered all questions, the subject worked through an illustrative example. ${ }^{8}$ Following completion of the example, the participant placed a bid on the bidding sheet (Step 3). In Step 4 , the administrator explained that if the participant won the auction, she would be contacted by telephone within three days after the show. Upon receipt of payment for the card, the card would be sent to her via courier, postage free.

In the nondealer experiments, the treatment type was changed at the top of each hour, so subjects' treatment type was determined based on the time they visited the auction table at the card show. The dealer treatments took place in the same fashion as the nondealer treatments, with one exception. Instead of waiting for participants to arrive at the auction booth, the administrator visited each dealer at his/her booth before the sportscard show opened, alternating the auction format and card type. The nondealer treatments took approximately 14 hours to complete (12 P.M. to 7 P.M. on Saturday and Sunday), while the dealer treatments took about five hours (7 A.M. to 12 noon on Saturday). ${ }^{9}$

\section{Results}

Table 1 summarizes the experimental data. ${ }^{10}$ The first row in Table 1 shows the means for each treatment type and reveals that dealers' bids are significantly higher than nondealers' bids for each auction type. In addition, the number of zero bids in each treatment shows a marked increase when moving from dealer to

\footnotetext{
${ }^{8}$ To test whether subjects understood the auction mechanisms, I ran a pilot study in November 1998 at a similar sportscard show in Orlando. On completion of these hypothetical auctions, subjects answered questions about their understanding of the auction rules. Approximately 15 people took part in each auction type, and no one had any problem understanding the allocation and price rules.

${ }^{9}$ The dealer sessions were completed in a more timely manner because the dealers (in their booths) were more accessible.

${ }^{10}$ As an external validity check, consider the relationship between winning bids (given in rows 3 and 4 of Table 1) and book value. The auction market prices are reasonably close to the listed PSA book value. The top two bids from each auction type are: (actual auction, dealers: $\$ 275, \$ 180$; nondealers: $\$ 230, \$ 230$ ), (hypothetical with cheap talk auction: dealers: $\$ 500, \$ 350$; nondealers: $\$ 330, \$ 140$ ); and (hypothetical: dealers: $\$ 600, \$ 400$; nondealers: $\$ 350, \$ 330$ ). The percentage of book value captured in the actual and hypothetical auctions are in the range of values in other related studies (see, e.g., List and Shogren, 1998a).
}

nondealer auctions. These findings are consistent with previous studies (e.g., List and Lucking-Reiley, 2000), and illustrate that dealer demand curves are located above ordinary consumer demand curves.

At issue is the gap between actual and hypothetical behavior, with and without cheap talk. In the dealer treatments, mean bids in both hypothetical regimes are greater than the average real bid; whereas in the nondealer treatments, mean bids in the actual and hypothetical with cheap talk auctions are similar, but much lower than the mean hypothetical bid. The ratio of mean hypothetical to mean real is approximately $1.85-1.95$ for both dealers and nondealers. These ratios are in accord with results from other card auctions that use ex post techniques to calibrate actual and hypothetical behavior (see, e.g., List and Shogren, 1998a).

The fourth and fifth rows in Table 1 contain parametric $t$-tests for the equivalency of mean bids across auction types: $H_{0}: \bar{x}_{i}=\bar{x}_{j}$, where $\bar{x}$ represents mean bid. Since there are three auction types in each group, I compute three separate $t$-tests for each subsample. Table 1 is read as follows: the dealer two-tailed $t$-test of hypothetical versus actual is at the intersection of row 5, column 3, and indicates $t=-2.65$, which suggests the two means are significantly different at the $p<0.01$ level.

In the dealer auctions, statistics in row 5 show that hypothetical bids are not significantly different from hypothetical with cheap talk bids at conventional levels $(t=-0.32)$. Conversely, $t$-tests in rows 5 and 6 indicate that mean bids from the actual auctions are statistically different from mean bids in the hypothetical $(t=-2.65)$ and hypothetical with cheap talk $(t=-2.46)$ auctions at the $p<0.05$ level. Nonparametric Mann-Whitney tests, contained in rows 7 and 8 of Table 1, which test whether the sampled populations have identical probability distributions, reveal the same insights - the distribution of actual bids is to the left of both hypothetical bid distributions $(z=-2.45 ; z=-2.27)$, while the hypothetical distributions are situated similarly $(z=-0.22)$. These results suggest that although bids in the hypothetical with cheap talk design are lower than bids in the hypothetical auction, the cheap talk design failed to eliminate hypothetical bias in the dealer valuation exercises. 
Table 1-Summary Statistics and UnConditional Tests of Equivalency

\begin{tabular}{|c|c|c|c|c|c|c|}
\hline & \multicolumn{3}{|c|}{ Dealers } & \multicolumn{3}{|c|}{ Nondealers } \\
\hline & $\begin{array}{c}\text { Hypothetical } \\
\text { auction } \\
N=41\end{array}$ & $\begin{array}{l}\text { Hypothetical } \\
\text { auction } \\
\text { with cheap } \\
\text { talk } \\
N=40\end{array}$ & $\begin{array}{c}\text { Actual } \\
\text { auction } \\
N=40\end{array}$ & $\begin{array}{c}\text { Hypothetical } \\
\text { auction } \\
N=89\end{array}$ & $\begin{array}{l}\text { Hypothetical } \\
\text { auction with } \\
\text { cheap talk } \\
N=75\end{array}$ & $\begin{array}{c}\text { Actual } \\
\text { auction } \\
N=86\end{array}$ \\
\hline Mean bid & $\begin{array}{c}\$ 116.09 \\
(\$ 121.50)\end{array}$ & $\begin{array}{c}\$ 107.89 \\
(\$ 107.93)\end{array}$ & $\begin{array}{c}\$ 59.56 \\
(\$ 61.20)\end{array}$ & $\begin{array}{c}\$ 49.03 \\
(\$ 79.96)\end{array}$ & $\begin{array}{c}\$ 26.15 \\
(\$ 46.01)\end{array}$ & $\begin{array}{c}\$ 25.60 \\
(\$ 46.23)\end{array}$ \\
\hline Zero bids & 2 & 3 & 2 & 23 & 28 & 31 \\
\hline Top 2 bids & $\begin{array}{l}\$ 600 \\
\$ 400\end{array}$ & $\begin{array}{l}\$ 500 \\
\$ 350\end{array}$ & $\begin{array}{l}\$ 275 \\
\$ 180\end{array}$ & $\begin{array}{l}\$ 350 \\
\$ 330\end{array}$ & $\begin{array}{l}\$ 330 \\
\$ 140\end{array}$ & $\begin{array}{l}\$ 230 \\
\$ 230\end{array}$ \\
\hline $\begin{array}{l}t \text {-test of means, } \\
\text { hypothetical } \\
\text { versus }\end{array}$ & - & $t=-0.32$ & $t=-2.65^{*}$ & - & $t=-2.29 *$ & $t=-2.38 *$ \\
\hline $\begin{array}{l}t \text {-test of means, } \\
\text { hypothetical with } \\
\text { cheap talk versus }\end{array}$ & $t=-0.32$ & - & $t=-2.46^{*}$ & $t=-2.29 *$ & - & $t=-0.07$ \\
\hline $\begin{array}{l}\text { Mann-Whitney test, } \\
\text { hypothetical } \\
\text { versus }\end{array}$ & - & $z=\begin{array}{c}797 \\
z-0.22\end{array}$ & $\begin{array}{c}562^{*} \\
z=-2.45\end{array}$ & - & $\begin{array}{c}2,732 * \\
z=-1.96\end{array}$ & $\begin{array}{c}3,080^{*} \\
=-2.26\end{array}$ \\
\hline $\begin{array}{l}\text { Mann-Whitney test, } \\
\text { hypothetical with } \\
\text { cheap talk versus }\end{array}$ & $\begin{array}{c}797 \\
z=-0.22\end{array}$ & - & $\begin{array}{c}565^{*} \\
z=-2.27\end{array}$ & $\begin{array}{c}2,732 * \\
z=-1.96\end{array}$ & - & $\begin{array}{c}3,143 \\
z=-0.29\end{array}$ \\
\hline
\end{tabular}

Notes: Standard errors are in parentheses beneath means. Cell entries for hypotheses tests are row treatment versus column treatment. Mann-Whitney test is for independent samples and since the number of observations is larger than 30 , the large-sample $z$-test is used. The large-sample $z$-test's null and alternative hypotheses are given by:

$H_{0}$ : Two sampled populations have identical probability distributions.

$H_{a}$ : The probability distribution for population $A$ is shifted to the right or to the left of that for population $B$.

* Significantly different values at the two-tailed $p<0.05$ level.

Results from the nondealer treatments stand in stark contrast to those in the dealer auctions. $t$-tests in rows 5 and 6 suggest the average hypothetical bid is statistically different from the mean hypothetical with cheap talk and mean actual bid at the $p<0.05$ level $(t=-2.29$; $t=-2.38$ ). In addition, the mean actual bid is not statistically different from the hypothetical with cheap talk mean bid at conventional significance levels $(t=-0.07)$. Mann-Whitney tests of whether the sampled populations have identical probability distributions reveal the same insights-actual and hypothetical with cheap talk bids are significantly less than bids in the hypothetical regime $(z=-1.96 ; z=$ $-2.26)$. These results suggest that the hypothetical with cheap talk design effectively eliminated hypothetical bias for ordinary consumers.

Although these findings are suggestive, they may be an artifact of variables left uncontrolled, such as subject-specific characteristics that af- fect bidding behavior. ${ }^{11}$ To supplement the results in Table 1, I estimate empirically the following bid function:

$$
\begin{aligned}
\text { Bid }_{i}= & \beta_{0}+\beta_{1} D_{\text {real }}+\beta_{2} D_{\text {cheaptalk }} \\
& +\sum_{j=3}^{J} \beta_{j} X_{i j}+e_{i}
\end{aligned}
$$

where $B i d_{i}$ is subject $i$ 's bid for the Cal Ripken, Jr. 1982 Topps Traded card, $D_{\text {real }}$ ( $\left.D_{\text {cheaptalk }}\right)$ is a dichotomous variable set equal to one if the auction type is real (hypothetical with cheap talk), and 0 otherwise; $X_{i j}$ are socioeconomic characteristics believed to affect bidding behavior, and $e_{i}$ is a well-behaved error term. A few

\footnotetext{
${ }^{11}$ Given that subjects were randomly allocated into the three treatments for both dealer and nondealer auctions, this analysis may be unnecessary, but it does provide a robustness check of the important findings.
} 
important aspects of equation (1) are worthy of brief mention. First, the dummy variable indicator for hypothetical auction is omitted from the equation, and therefore $\beta_{1}$ and $\beta_{2}$ represent deviations from behavior in the hypothetical scenario. The results of interest are whether $\beta_{1}$ and $\beta_{2}$ are significantly different from zero, and whether they are equal to one another. Second, variables included in $X_{i j}$ are similar to CT. These variables include age, income, experience with the sportscard market, and gender, where gender $=1$ if male, and 0 if female. ${ }^{12}$ Third, since there is a nontrivial number of zero bids, I present estimation results from models of ordinary least squares (OLS) and Tobit, which is estimated via maximum likelihood.

Econometric estimates of equation (1) are presented in Table 2. Because the Tobit and OLS models yield similar insights, I will focus the discussion on the coefficient estimates from the OLS models. For both bidder types, the empirical estimates serve to strengthen the findings in Table $1 .{ }^{13}$ In the dealer auctions, the coefficient of $D_{\text {real }}$ is negative and significantly different from zero at the $p<0.05$ level. Yet, the coefficient of $D_{\text {cheaptalk }}$ is not significantly different from zero at conventional levels, suggesting behavior in the cheap talk auction is not different from behavior in the purely hypothetical auction for dealers. Furthermore, results from a likelihood-ratio test in the bottom panel of Table 2 suggest that $\beta_{1} \neq \beta_{2}\left(\chi^{2}(1\right.$ d.f. $)=$ $5.60)$, implying subjects behaved differently across the actual and hypothetical with cheap talk auctions at the $p<0.05$ level. These results indicate that even after controlling for subject characteristics, the empirical evidence suggests that the cheap talk design failed to eliminate bias in the dealer treatments.

Empirical results in the nondealer treatments

\footnotetext{
${ }^{12}$ A one way ANOVA test indicates that the respective samples for the three treatments do not differ by socioeconomic characteristics in either the dealer or nondealer treatments. Experience and age are continuous variables, while income is a categorical variable. Income is yearly income from all sources before taxes and has eight categories: (1) $<\$ 10,000$; (2) \$10,000-\$19,999; (3) \$20,000-\$29,999; (4) $\$ 30,000-\$ 39,999 ;(5) \quad \$ 40,000-\$ 49,999 ;$ (6) $\$ 50,000-$ $\$ 74,999$; (7) $\$ 75,000-\$ 99,999$; and (8) > $\$ 100,000$.

${ }^{13}$ Coefficient estimates of the subject characteristics are largely insignificant, except for the coefficient of income, which is marginally significant and suggests that the 1982 Topps Traded Cal Ripken, Jr. card is a normal good.
}

are in strong favor of the cheap talk design. Estimates in columns 3 and 4 of Table 2 imply that bidding in the actual and hypothetical with cheap talk auctions is different from bidding in the hypothetical auction. Coefficient estimates of -19.65 and -21.59 suggest that bids in the actual and hypothetical with cheap talk auctions were $\$ 19.65$ and $\$ 21.59$ less than bids in the hypothetical auction, controlling for other factors. Both coefficients are significantly different from zero at the $p<0.05$ level. Additionally, a likelihood-ratio test suggests that these coefficients are not statistically different at conventional significance levels $\left(\chi^{2}(1\right.$ d.f. $\left.)=0.15\right)$, indicating nondealers behaved similarly in the actual and hypothetical with cheap talk auctions. These results lend strong support to the above findings-for consumers, the cheap talk design was successful in eliminating hypothetical bias, even after controlling for subjectspecific characteristics.

The main empirical finding concerning the anomalous behavior across consumer types is consistent with conclusions from Penny Burns' (1985) sequential English auctions. Burns (1985) compared the price strategy choices of inexperienced students with those of highly experienced wool buyers and found that the wool buyers had developed valuation strategies that tended to be immutable. The bidding strategy anomaly observed in Burns' data is well summed up by one of the wool buyers, who commented "With us it is a reflex action. Possibly others could orientate themselves more quickly" (Burns, 1985 pp. 150-51).

The autonomic decision-making exhibited by sportscard dealers and wool buyers is in accord with previous findings on the effects of external signals in the value creation stage. One of the most important aspects of determining the persuasive impact of a message, such as the cheap talk script, is the processing mode of the receiver. Past work on the complex organization of the human mind suggests that humans have special and highly developed cognitive mechanisms for dealing with signals (Elizabeth Hoffman et al., 1998). For example, evidence in the social psychology literature suggests that an individual will reject external information on a subject for which they have previous knowledge and feel strongly about (see, e.g., Yaacov Y. I. Vertzberger, 1990). Indeed, Elana Michelson (1999) makes a similar point by noting 
TABle 2-Estimation Results For Bid Function

\begin{tabular}{|c|c|c|c|c|}
\hline \multirow[b]{2}{*}{ Variable } & \multicolumn{2}{|c|}{ Dealers } & \multicolumn{2}{|c|}{ Nondealers } \\
\hline & $\begin{array}{l}\text { OLS bid } \\
\text { function }\end{array}$ & $\begin{array}{l}\text { Tobit bid } \\
\text { function }\end{array}$ & $\begin{array}{l}\text { OLS bid } \\
\text { function }\end{array}$ & $\begin{array}{l}\text { Tobit bid } \\
\text { function }\end{array}$ \\
\hline Constant & $111.85^{*}$ & $110.43^{*}$ & 34.11 & 9.60 \\
\hline$D_{\text {real }}$ & $\begin{array}{c}-64.28 * \\
(22.31)\end{array}$ & $\begin{array}{c}(44.39) \\
-65.03^{*} \\
(22.77)\end{array}$ & $\begin{array}{r}-19.65^{*} \\
(9.51)\end{array}$ & $\begin{array}{c}(24.80) \\
-27.94 * \\
(13.03)\end{array}$ \\
\hline$D_{\text {cheaptalk }}$ & $\begin{array}{c}-12.55 \\
(22.25)\end{array}$ & $\begin{array}{c}-14.71 \\
(22.75)\end{array}$ & $\begin{array}{c}-21.59^{*} \\
(9.88)\end{array}$ & $\begin{array}{c}-30.88^{*} \\
(13.62)\end{array}$ \\
\hline Income & $\begin{array}{c}10.91^{*} \\
(5.60)\end{array}$ & $\begin{array}{c}9.98 \\
(5.75)\end{array}$ & $\begin{array}{c}4.38 \\
(2.31)\end{array}$ & $\begin{array}{c}5.88 \\
(3.17)\end{array}$ \\
\hline Age & $\begin{array}{c}-0.01 \\
(0.95)\end{array}$ & $\begin{array}{c}0.25 \\
(0.98)\end{array}$ & $\begin{array}{c}-0.02 \\
(0.34)\end{array}$ & $\begin{array}{c}0.20 \\
(0.47)\end{array}$ \\
\hline Experience & $\begin{array}{c}-1.85 \\
(1.14)\end{array}$ & $\begin{array}{c}-2.17 \\
(1.17)\end{array}$ & $\begin{array}{c}-0.11 \\
(0.50)\end{array}$ & $\begin{array}{c}-0.68 \\
(0.74)\end{array}$ \\
\hline Gender & $\begin{array}{c}-18.78 \\
(31.51)\end{array}$ & $\begin{array}{c}-22.01 \\
(32.02)\end{array}$ & $\begin{array}{c}0.51 \\
(13.19)\end{array}$ & $\begin{array}{c}1.05 \\
(18.29)\end{array}$ \\
\hline $\begin{array}{l}\chi^{2}\left(\beta_{1}=\beta_{2}\right) \\
\text { Degrees of freedom } \\
N\end{array}$ & $\begin{array}{l}5.60 * \\
(1) \\
121\end{array}$ & $\begin{array}{c}4.78^{*} \\
(1) \\
121\end{array}$ & $\begin{array}{c}0.15 \\
(1) \\
250\end{array}$ & $\begin{array}{c}0.10 \\
(1) \\
250\end{array}$ \\
\hline
\end{tabular}

Notes: Dependent variable is subject's bid. $D_{\text {real }}$ and $D_{\text {cheaptalk }}$ are dichotomous variables indicating auction type real and hypothetical with cheap talk, gender $=1$ if male, 0 otherwise. $F\left(\beta_{1}=\beta_{2}\right)$ and $\chi^{2}\left(\beta_{1}=\beta_{2}\right)$ are $F$ - and likelihood-ratio tests of whether the coefficient of the real and cheap talk designs are different. Standard errors in parentheses under coefficient estimates. No corrections were made for nonspherical disturbances. However, estimated models that correct for heteroskedasticity yield similar findings to those presented in Table 2 .

* Significant at the $p<0.05$ level.

that "Theories of experiential learning have tended to view experience as liberating ... as it frees us ... from the contagious influence of others ..." (Michelson p. 140). ${ }^{\mathbf{1 4}}$

The burgeoning CVM literature is beginning to recognize the important link between the reliability of stated values and experience with the good. Trudy Ann Cameron and Jeffrey Englin (1997 p. 310) note "that CVM estimates of willingness to pay for some environmental goods are only reliable if respondents have had some degree of experience with the commodity being valued." In a similar spirit, the empirical evidence presented herein suggests that the cheap talk design may not eliminate bias for

\footnotetext{
${ }^{14}$ In personal correspondence, Vernon L. Smith provided a related explanation: "[think of] context specific specialization based on learning. Attentional resources in the brain are very scarce. We economize on them by developing learned responses that enable autonomic decisionmaking. To change you have to kick in the higher opportunity cost of mental resources to overcome the transactions cost of switching."
}

consumers that have past experience with the good. If this finding is robust for other goods and in other contexts, it represents a serious practical problem for the cheap talk design, as experienced users of any good are important in defining the good's value.

\section{Concluding Remarks}

Contingent valuation is a widely used method of obtaining value estimates for nonmarket commodities. A persistent issue is whether responses to CVM questions provide an accurate depiction of true values. Some recently published studies provide evidence that suggests hypothetical bias is an important factor that drives a wedge between intentions and actions. Using laboratory techniques, Cummings and Taylor (1999) present compelling evidence that indicates hypothetical bias can be eliminated by an appropriate cheap talk design. I go to the field to test this scheme and find positive evidence that cheap talk does mitigate hypothetical bias for certain consumer types. But the cheap 
talk script was not able to reduce hypothetical bias for bidders with experience in the market. Although these results represent a step forward, they also present a challenge for future researchers to design an effective mechanism, $e x$ post or ex ante, to eliminate hypothetical bias for all subject types.

\section{Appendix A: Subject Instructions for Actual ViCKREY AUCTION}

Welcome to Lister's Auctions. You have the opportunity to bid in an auction for the baseball card on the table. If you are a card dealer you will be grouped with other card dealers, if you are a nondealer you will be grouped with other nondealers.

The card up for auction is the 1982 Cal Ripken, Jr. Topps Traded PSA 8 on the table.

Auction Rules.-A sealed-bid second-price auction will be used to determine the winner of each item. Thus, if your bid of $\$ X$ is the highest bid and the next highest bid is $\$ X-$ 5 , you win the card but only pay $\$ X-5$. Under this bidding mechanism it is best for you to bid your true value because overbidding may cause you to pay too much and underbidding decreases your odds of winning the item.

I will accept bids until Sunday at 5 P.M. On Monday morning I will order the bids from highest to lowest in order to determine the winner of the card.

For example, if the top four bids are ranked highest to lowest as follows:

\$A
\$B
\$C
\$D

The bidder who bid $\mathbf{\$ A}$ wins the card and pays $\mathbf{\$ B}$.

Given that the winner of the card will pay a price equal to the amount of the second-highest bid, please place your bid below:

Cal Ripken, Jr. 1982 Topps “Traded" NRMT PSA $8 \$$

After the winner pays me cash or check for the card, the card will be awarded to the winner (we pay postage). Please sign the dotted line below to verify your bids. Also, please provide your name, telephone number, and mailing address below:

Signature

Name

Address

Phone\#

I now want to ask you a few more questions. These questions will be used for statistical purposes only. THIS INFORMATION WILL BE KEPT STRICTLY CONFIDENTIAL AND WILL BE DESTROYED UPON COMPLETION OF THE STUDY.

1. How long have you been dealing with sportscards and memorabilia? ___ yrs.

2. If you are a dealer, how long have you been an active dealer? yrs.

3. Gender: 1) Male 2) Female.

4. Age ___ Date of Birth

5. What is the highest grade of education that you have completed? (Circle one)

1) Eighth Grade 3) 2-Year College 5) 4-Year College

2) High School 4) Other Post-High 6) Graduate School School Education

6. What is your approximate yearly income from all sources, before taxes?
1) Less than $\$ 10,000$
5) $\$ 40,000$ to $\$ 49,999$
2) $\$ 10,000$ to $\$ 19,999$
6) $\$ 50,000$ to $\$ 74,999$
3) $\$ 20,000$ to $\$ 29,999$
7) $\$ 75,000$ to $\$ 99,999$
4) $\$ 30,000$ to $\$ 39,999$
8) $\$ 100,000$ or over

\section{Appendix B: Cheap Talk Additional EXPERIMENTAL INSTRUCTIONS}

Before you bid, I want to talk to you about a problem that we have in studies like this one. As I told you a minute ago, this is a hypothetical auction-not a real one. No one will actually pay money at the end of the auction. But, I also asked you to bid as though the result of your bid could involve a real cash payment by you.

And that's the problem.

In most studies of this kind, folks seem to have a hard time doing this. They bid differently in a hypothetical auction, where they don't really have to pay money, than they do in a real auction, where they really could have to pay money. For example, in a recent study, several different groups of people bid in an auction just like the one you are about to bid in. Payment was hypothetical for these groups, as it will be 
for you. No one had to pay money if they won the auction. The results of these studies were that on average, across the groups, people overstated their actual willingness to pay by 150 percent. That's quite a difference, isn't it?

We call this a "hypothetical bias." "Hypothetical bias" is the difference that we continually see in the way people respond to hypothetical auctions as compared to real auctions-just like the overbidding example presented above.

In the real auction, where people knew they would have to pay money if they actually won, people lowered their bid drastically.

How can we get people to think about their bid in a hypothetical auction like they think in a real auction, where if a person wins he/she will really have to pay money? How do we get them to think about what it means to really dig into their pocket and pay money, if in fact they really aren't going to have to do it?

Let me tell you why I think that we continually see this hypothetical bias, why people behave differently in a hypothetical auction than they do when the auction is real. I think that when we bid in a hypothetical auction we bid our best guess of what the good is really worth on the open market. But, when the auction is real, and we would actually have to spend our money if we win, we think a different way: if I spend money on this, that's money I don't have to spend on other things ... we bid in a way that takes into account the limited amount of money we have ... This is just my opinion, of course, but it's what I think may be going on in hypothetical auctions.

So, if I were in your shoes, and I was asked to bid on the sportscard on the table, I would think about how I feel about spending my money this way. When I got ready to bid, I would ask myself: if this were a real auction, and I had to pay $\$ X$ if I win, do I really want to spend my money this way? If I really did, I would bid \$X; if I didn't, I would bid less than $\$ X$, but a value that equaled my true value. That's just my opinion, of course. You must do whatever you want to do.

In any case, I ask you to bid just exactly as you would bid if you were really going to face the consequences of your bid: which is to pay money if you win the auction.

Please keep this in mind in our auction.

\section{REFERENCES}

Burns, Penny. "Experience and Decisionmaking: A Comparison of Students and Businessmen in a Simulated Progressive Auction," in Vernon L. Smith, ed., Research in experimental economics, Vol. 3. Greenwich, CT: JAI Press, 1985, pp. 139-57.

Cameron, Trudy Ann and Englin, Jeffrey. "Respondent Experience and Contingent Valuation of Environmental Goods." Journal of Environmental Economics and Management, July 1997, 33(3), pp. 296-313.

Coursey, Don L.; Hovis, John L. and Schulze, William D. "The Disparity between Willingness to Accept and Willingness to Pay Measures of Value." Quarterly Journal of Economics, August 1987, 102(3), pp. 67990.

Cummings, Ronald G.; Harrison, Glenn W. and Rutström, E. Elisabet. "Homegrown Values and Hypothetical Surveys: Is the Dichotomous Choice Approach Incentive Compatible?" American Economic Review, March 1995, 85(1), pp. 260-66.

Cummings, Ronald G. and Taylor, Laura $O$. "Unbiased Value Estimates for Environmental Goods: A Cheap Talk Design for the Contingent Valuation Method." American Economic Review, June 1999, 89(3), pp. 649-65.

Diamond, Peter A. and Hausman, Jerry A. "Contingent Valuation: Is Some Number Better than No Number?" Journal of Economic Perspectives, Fall 1994, 8(4), pp. 45-64.

Hoffman, Elizabeth; McCabe, Kevin A. and Smith, Vernon L. "Behavioral Foundations of Reciprocity: Experimental Economics and Evolutionary Psychology." Economic Inquiry, July 1998, 36(3), pp. 335-52.

Kagel, John. "Auctions: A Survey of Experimental Research," in John H. Kagel and Alvin E. Roth, eds., Handbook of experimental economics. Princeton, NJ: Princeton University Press, 1995, pp. 501-85.

List, John A. and Lucking-Reiley, David. "Demand Reduction in Multiunit Auctions: Evidence from a Sportscard Field Experiment." American Economic Review, September 2000, 90(4), pp. 961-72.

List, John A. and Shogren, Jason F. "Calibration of the Difference between Actual and Hypothetical Valuations in a Field Experiment." 
Journal of Economic Behavior and Organization, October 1998a, 37(2), pp. 193-205. . "The Deadweight Loss of Christmas:

Comment." American Economic Review, December 1998b, 88(5), pp. 1350-55. . "Price Information and Bidding Behavior in Repeated Second-Price Auctions." American Journal of Agricultural Economics, November 1999, 81(4), pp. 942-49.

Michelson, Elana. "Carnival, Paranoia, and Experimental Learning." Studies in the Education of Adults, October 1999, 32(2), pp. 140-52.

Mitchell, Robert Cameron and Carson, Richard T. Using surveys to value public goods: The contingent valuation method. Washington, DC: Resources for the Future, 1989.

Neill, Helen; Cummings, Ronald; Ganderton, Philip; Harrison, Glenn and McGuckin,
Thomas. "Hypothetical Surveys and Real Economic Commitments." Land Economics, May 1994, 70(2), pp. 145-54.

Poe, Gregory; Clark, Jeremy and Schulze, William. "Can Hypothetical Questions Predict Actual Participation in Public Programs?: A Field Validity Test Using a Provision Point Mechanism." Working paper, Cornell University, 1997.

Vertzberger, Yaacov Y. I. The world in their minds: Information processing, cognition, and perception in foreign policy decisionmaking. Stanford, CA: Stanford University Press, 1990.

Vickrey, William. "Counterspeculation, Auctions, and Competitive Sealed Tenders." Journal of Finance, March 1961, 16(1), pp. $8-37$. 